Article

\title{
Synthesis of Novel Benzazole Derivatives and Evaluation of Their Antidepressant-Like Activities with Possible Underlying Mechanisms
}

\author{
Gamze Tokgöz ${ }^{1}$, Ümide Demir Özkay ${ }^{1, *}$, Derya Osmaniye ${ }^{2,3}$, Nazlı Turan Yücel ${ }^{1}{ }^{1}$, \\ Özgür Devrim Can ${ }^{1}$ and Zafer Asım Kaplancıklı ${ }^{2}$ \\ 1 Department of Pharmacology, Faculty of Pharmacy, Anadolu University, Eskişehir 26470, Turkey; \\ eczgamzetokgoz@gmail.com (G.T.); nazlituran@anadolu.edu.tr (N.T.Y.); ozgurdt@anadolu.edu.tr (Ö.D.C.) \\ 2 Department of Pharmaceutical Chemistry, Faculty of Pharmacy, Anadolu University, Eskişehir 26470, \\ Turkey; dosmaniye@anadolu.edu.tr (D.O.); zakaplan@anadolu.edu.tr (Z.A.K.) \\ 3 Doping and Narcotic Compounds Analysis Laboratory, Faculty of Pharmacy, Anadolu University, \\ Eskişehir 26470, Turkey \\ * Correspondence: udemir@anadolu.edu.tr; Tel.: +90-222-335-0580 (ext. 3751)
}

Received: 21 September 2018; Accepted: 1 November 2018; Published: 5 November 2018

\begin{abstract}
Novel benzazole derivative compounds $4 \mathbf{a}-\mathbf{4 h}$ were obtained by the reaction of corresponding 2-(benzazol-2-ylthio)acetohydrazide and appropriate 4-substituted benzaldehydes. The chemical structures of the synthesized compounds were elucidated by FT-IR, ${ }^{1} \mathrm{H}-\mathrm{NMR},{ }^{13} \mathrm{C}-\mathrm{NMR}$ and LCMS spectroscopic methods. Antidepressant-like effects of the compounds were evaluated by tail suspension test (TST) and modified forced swimming tests (MFST). Moreover, locomotor activities of the animals were assessed by an activity cage apparatus. In the series, compounds $\mathbf{4 a}, \mathbf{4 b}$, $4 \mathbf{e}$ and $4 \mathrm{f}($ at $50 \mathrm{mg} / \mathrm{kg})$ significantly decreased the immobility time of mice in both of the TST and MFST. The same compounds prolonged the swimming time of animals in MFST without any change in the climbing duration. These data indicated that compounds $\mathbf{4 a}, \mathbf{4 b}, \mathbf{4} \mathbf{e}$ and $\mathbf{4 f}$ possess significant antidepressant-like activities. Moreover, pre-treatments with $p$-chloro-phenylalanine methyl ester (an inhibitor of serotonin synthesis), NAN-190 (a 5- $\mathrm{HT}_{1 \mathrm{~A}}$ antagonist), ketanserin (a 5- $\mathrm{HT}_{2 \mathrm{~A} / 2 \mathrm{C}}$ antagonist), and ondansetron (a $5-\mathrm{HT}_{3}$ antagonist) reversed the exhibited pharmacological effects. Results of the mechanistic studies suggested the involvement of serotonergic system and contributions of $5-\mathrm{HT}_{1 \mathrm{~A}}, 5-\mathrm{HT}_{2 \mathrm{~A} / 2 \mathrm{C}}$ and $5-\mathrm{HT}_{3}$ receptors to the antidepressant-like effects of compounds $4 \mathbf{a}, \mathbf{4} \mathbf{b}, 4 \mathbf{e}$ and $4 \mathrm{f}$. Furthermore, unchanged locomotor activity of mice following the administrations of these four derivatives confirmed that the presented antidepressant-like effects are specific.
\end{abstract}

Keywords: activity cage test; antidepressant; benzazole; modified forced swimming test; tail suspension test

\section{Introduction}

Depression is a common and incapacitating mental health condition that is estimated to affect over 300 million people worldwide. The main symptoms of depression are sad mood, loss of interest or pleasure, low self-worth, feel of guilty, lack of concentration, anhedonia, suicidal thoughts, disrupted sleep, appetite or energy [1,2]. Clinically used antidepressant drugs such as selective serotonin reuptake inhibitors, tricyclic antidepressants, and monoamine oxidase inhibitors alleviate the symptoms of major depression. However low response rates, delayed onset of therapeutic action or various side effects associated with the use of current antidepressants are still major challenges in the management of this disease limiting the success of treatment and causing compliance problems in patients $[3,4]$. Therefore, studies for discovering and developing new antidepressant drugs are of great importance. 
The benzazole type compounds such as benzimidazoles and benzothiazoles are frequently preferred rings in drug development studies because of their widespread pharmacological activity potential. For example, various benzimidazole-based compounds have been reported for their antibacterial [5], anticancer [6], anti-HIV [7], anti-ulcer [8], anti-asthmatic [9], antidiabetic [10,11], anti-inflammatory [11], antihypertensive [12], cholinesterase inhibitory, and anti-oxidant [13] effects. Numerous benzothiazole derivatives have also been shown to induce antibacterial, antifungal, anticancer [14], anti-oxidant [15], antiviral [16], antituberculosis [17], antidiabetic [18], and anti-inflammatory [19] activities, so far.

Various compounds bearing benzimidazole or benzothiazole ring systems in their chemical structures have been demonstrated to possess potential for passing through the blood brain barrier and triggering some central nervous system (CNS)-related pharmacological activities. Actually, benzimidazole derivative compounds have been shown to induce antidepressant-like [20-22], antinociceptive $[23,24]$ and anticonvulsant $[10,11,25]$ activities. The same activities $[19,26-32]$ as well as anti-Alzheimer [33,34] and neuroprotective [35] effects have also been reported for compounds carrying benzothiazole groups. Therefore, based on the CNS-related activity potential of benzimidazole and benzothiazole ring systems, in the present study, we synthesized some novel compounds carrying both of these ring systems on their chemical scaffolds and investigated their potential antidepressant-like activities using some well-known in vivo methods.

\section{Results and Discussion}

\subsection{Chemistry}

The compounds were obtained through a four-step synthesis as presented in Scheme 1. Initially, 4-substituted benzaldehyde derivatives $\mathbf{1 a}-\mathbf{1} \mathrm{h}$ were prepared by refluxing 4 -fluorobenzaldehyde and appropriate secondary amines in DMF. Secondly, ethyl 2-(benzazol-2-yl-thio)acetates (2a,2 $\mathbf{b}$ ) were gained as a result of reactions between an appropriate benzazol-2-thiol and ethyl 2-chloroacetate. Thirdly, the reaction of compounds $\mathbf{2 a}, \mathbf{2} \mathbf{b}$ and excess of hydrazine hydrate afforded 2-((5-substitutedbenzazol-2-yl)thio)acetohydrazides $(\mathbf{3} \mathbf{a}, \mathbf{3} \mathbf{b})$, which were reacted with the appropriate 4-substituted benzaldeydes $\mathbf{1 a}-\mathbf{1 h}$ to afford the target compounds $\mathbf{4 a - 4 h}$. Structure elucidations of the final compounds were performed by IR, ${ }^{1} \mathrm{H}-\mathrm{NMR},{ }^{13} \mathrm{C}-\mathrm{NMR}$, and MS spectroscopic methods (see Supplementary Materials). 


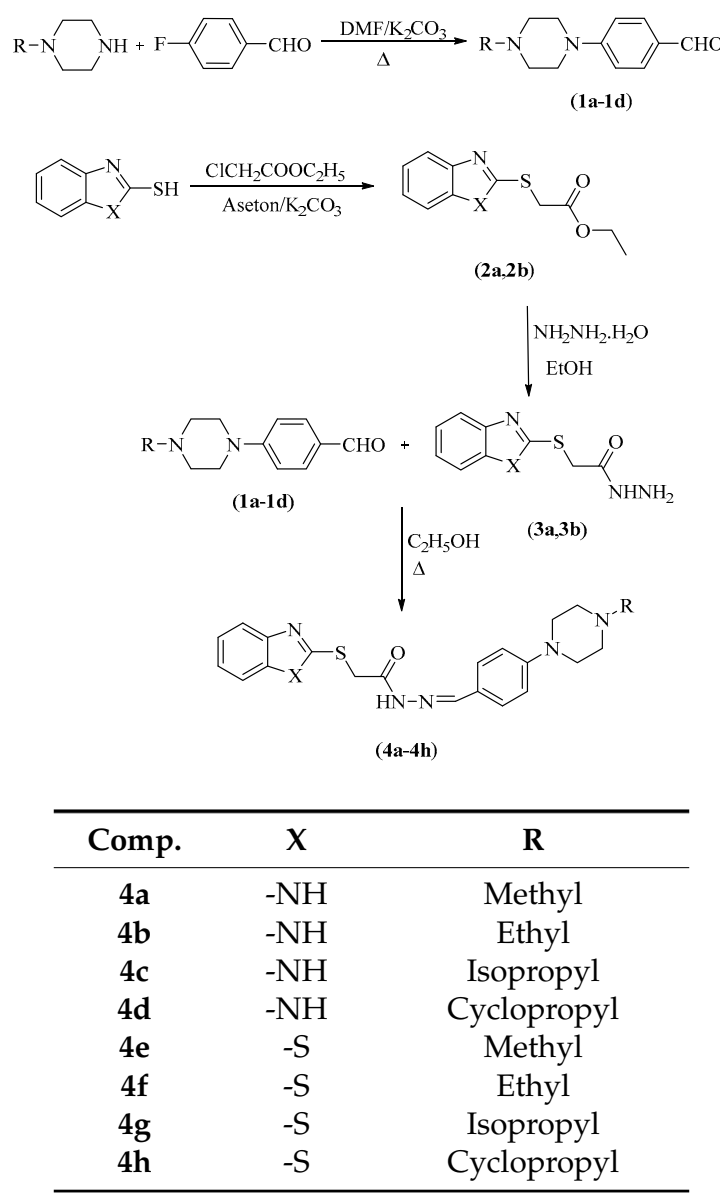

Scheme 1. Synthesis of the target compounds $4 \mathbf{a}-\mathbf{4 h}$.

\subsection{Pharmacology}

In this study, antidepressant-like effects of the test compounds were investigated with tail suspension test (TST) and modified forced swimming tests (MFST), which are commonly used methods in antidepressant-like activity screening studies [36-39].

In the TST, animals are hanged from their tails. Under this short-term and inescapable stressful condition, animals become immobile following some escape-oriented movements. In this test, the duration of "immobile posture" reflecting the behavioral despair is measured. It is known that various antidepressant drugs reduce the immobility time of animals and increase the escape-related movements in the TST [40-43]. The effects of the tested compounds and reference drug fluoxetine on the immobility time of mice in the TST are illustrated in Figure $1[\mathrm{~F}(9,60)=10.27, p<0.001]$. Tukey HSD multiple comparison tests following one-way ANOVA demonstrated that compounds $4 \mathbf{a}, 4 \mathbf{b}, \mathbf{4 e}, \mathbf{4 f}$ and reference drug fluoxetine significantly reduced the immobility time of animals pointing out the antidepressant-like effects of these compounds.

MFST, a modified version of Porsolt's forced swimming test, is based on the behavioral analysis of animals that are forced to swim in an inescapable narrow cylinder. Animals struggle to escape from this environment and after a while, they develop an immobile posture. This immobility behavior is considered as "behavioral despair". Various antidepressant drugs have been reported to reduce immobility times of rodents in MFST [42-44]. In this study, effects of the test compounds and fluoxetine on immobility time of mice in the MFST was shown in Figure $2[\mathrm{~F}(9,60)=9.95, p<0.001]$. Results of the post-hoc analysis indicated that compounds $\mathbf{4 a}, \mathbf{4 b}, \mathbf{4 e}, \mathbf{4 f}$ and fluoxetine caused significant decreases in the immobility time of mice in MFST. Findings of the MFST, revealing the antidepressant-like effects of compounds $\mathbf{4 a}, \mathbf{4 b}, \mathbf{4 e}$ and $\mathbf{4 f}$, supported the data obtained from the TST. 


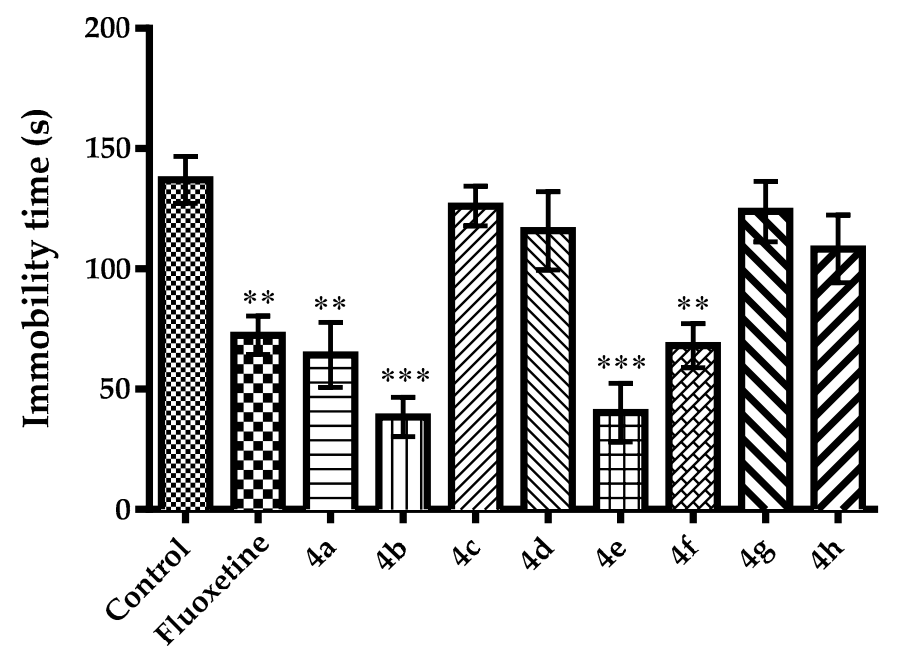

Figure 1. The effect of $4 \mathbf{a}-\mathbf{4 h}(50 \mathrm{mg} / \mathrm{kg})$ and fluoxetine $(20 \mathrm{mg} / \mathrm{kg})$ on immobility time of animals in the tail suspension test. ${ }^{* *} p<0.01,{ }^{* * *} p<0.001$, compared with control group; One way analysis of variance followed by Tukey HSD multiple comparison test, $\mathrm{n}=7$.

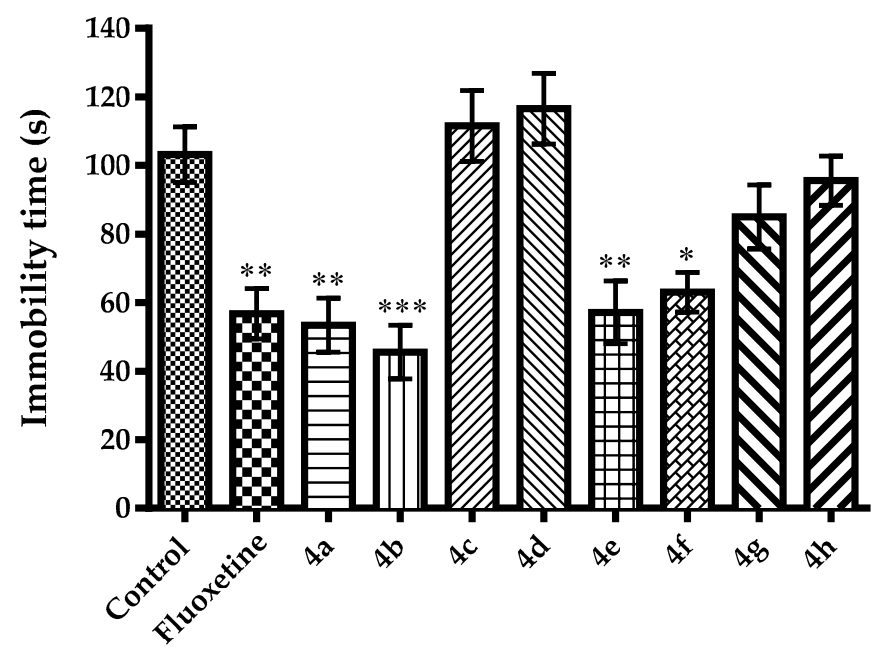

Figure 2. The effect of $4 \mathbf{a}-\mathbf{4 h}(50 \mathrm{mg} / \mathrm{kg})$ and fluoxetine $(20 \mathrm{mg} / \mathrm{kg})$ on immobility time of animals in the modified forced swimming test. ${ }^{*} p<0.05,{ }^{* *} p<0.01,{ }^{* * *} p<0.001$, compared with control group; One way analysis of variance followed by Tukey HSD multiple comparison test, $\mathrm{n}=7$.

Different from Porsolt's forced swimming test, in MFST, durations of active movements such as swimming and climbing are taken into account in addition to the immobility behaviors of the animals. Evaluation of the active behaviors is critical, since it provides some additional clues related to the possible neurotransmitter systems playing role in the antidepressant-like effect of a test compound [45-48]. Namely, agents affecting serotonergic neurotransmission are known to reduce immobility and increase swimming times, in MFST. On the other hand, agents increasing catecholaminergic neurotransmission in the synaptic cleft have been reported to enhance climbing time while shortening the immobility durations of animals [47]. In the present study, effects of test compounds and fluoxetine on swimming and climbing time of mice in the MFST was demonstrated in Figure $3[\mathrm{~F}(9,60)=5.53, p<0.001]$ and Figure $4[\mathrm{~F}(9,60)=0.82, p>0.05]$, respectively. Results of the post-hoc analysis indicated that compounds $4 \mathbf{a}, \mathbf{4 b}, \mathbf{4 e}, \mathbf{4 f}$ and fluoxetine significantly increased the swimming duration of mice while reducing the immobility time. On the other hand, none of the test compounds altered the climbing time of the animals. Therefore, it can be suggested that antidepressant-like effects of the compounds $4 \mathbf{a}, \mathbf{4 b}, 4 \mathbf{e}$ and $\mathbf{4 f}$ might be related to the serotonergic rather than catecholaminergic mechanisms in the CNS. 


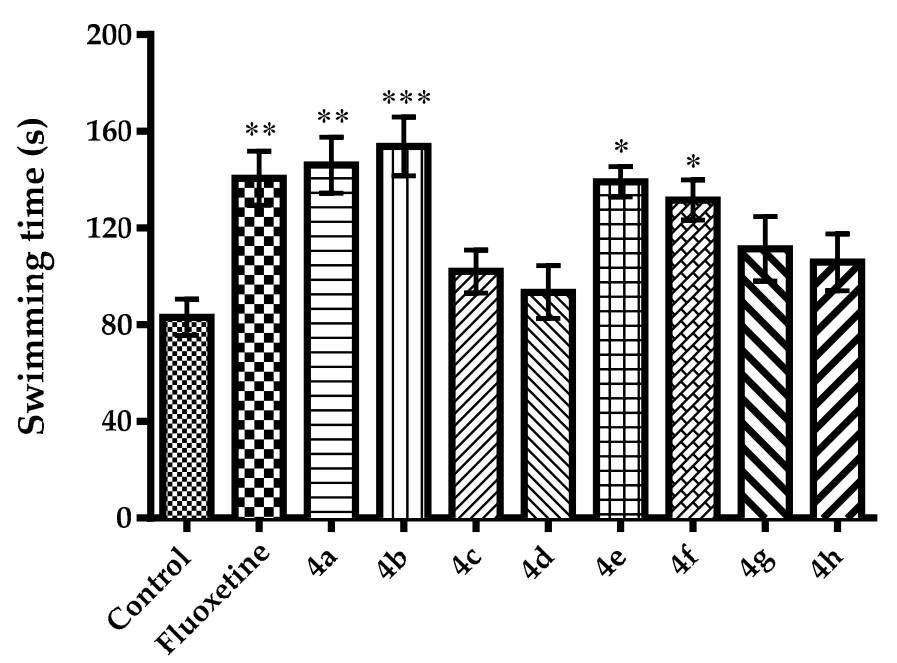

Figure 3. The effect of $4 \mathbf{a}-\mathbf{4 h}(50 \mathrm{mg} / \mathrm{kg})$ and fluoxetine $(20 \mathrm{mg} / \mathrm{kg})$ on swimming time of animals in the modified forced swimming test. ${ }^{*} p<0.05,{ }^{* *} p<0.01$, ${ }^{* * *} p<0.001$, compared with control group; One way analysis of variance followed by Tukey HSD multiple comparison test, $\mathrm{n}=7$.

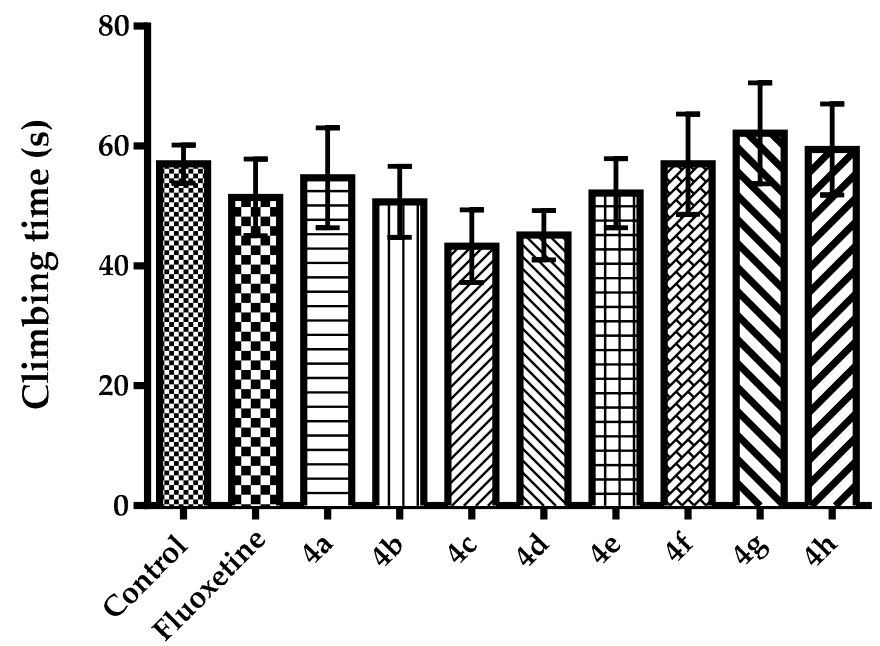

Figure 4. The effect of $4 \mathbf{a}-4 \mathrm{~h}(50 \mathrm{mg} / \mathrm{kg})$ and fluoxetine $(20 \mathrm{mg} / \mathrm{kg})$ on climbing time of animals in the modified forced swimming test. One way analysis of variance followed by Tukey HSD multiple comparison test, $\mathrm{n}=7$.

It is known that agents altering motor activity performances of animals may cause "false positive" or "false negative" results, in TST and MFST [40,42,49]. For this reason, spontaneous locomotor activities of animals were also evaluated, in this study. Effects of the test compounds on horizontal and vertical locomotor activities of mice in the activity cage test were presented in Figure $5[\mathrm{~F}(8,54)=3.32$, $p<0.01]$ and Figure $6[F(8,54)=4.52, p<0.001]$, respectively. Compounds $4 \mathbf{a}, 4 \mathbf{b}, 4 \mathbf{e}$ and $4 \mathbf{f}$, which show antidepressant-like activity in the TST and MFST, did not cause any significant changes in the horizontal and vertical spontaneous locomotor activities of the animals. These findings suggest that shortened immobility time of the animals in TST and MFST is not associated with stimulatory effects of compounds $\mathbf{4 a}, \mathbf{4 b}, \mathbf{4 e}$ and $\mathbf{4 f}$. In other words, observed antidepressant-like effects are specific. On the other hand, compound $\mathbf{4 d}$, which did not cause any changes in immobility or swimming time of mice, triggered a significant reduction both in the horizontal and vertical locomotor activities of animals. These decreases in the spontaneous locomotor activities may be directly related to neurosedative activity of compound $4 \mathbf{d}$ or possible effect of this compound on neuromuscular junction. Further studies are needed to clarify this issue. 


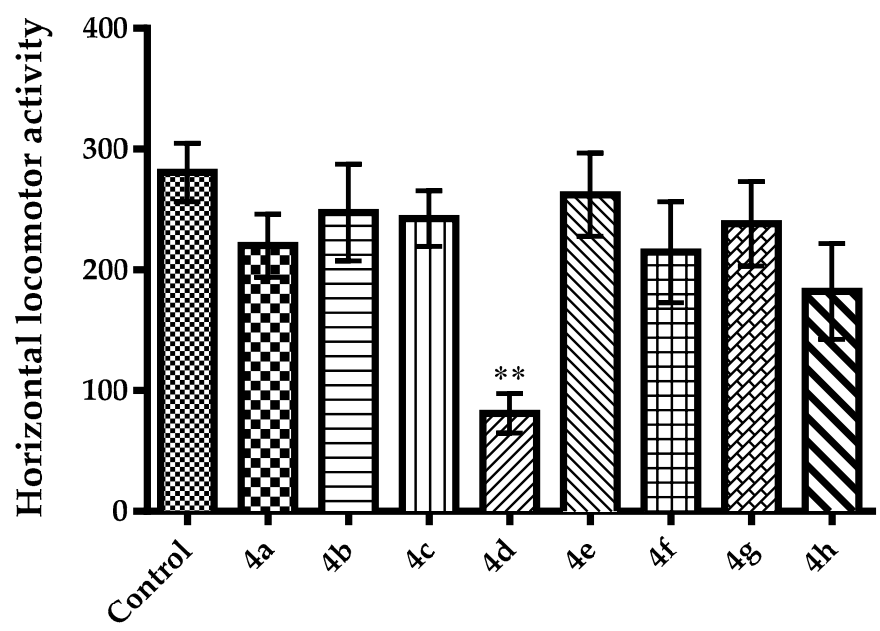

Figure 5. The effect of $4 \mathbf{a}-\mathbf{4 h}(50 \mathrm{mg} / \mathrm{kg})$ on horizontal locomotor activities of animals in the activity cage test. ${ }^{* *} p<0.01$, compared with control group; One way analysis of variance followed by Tukey HSD multiple comparison test, $\mathrm{n}=7$.

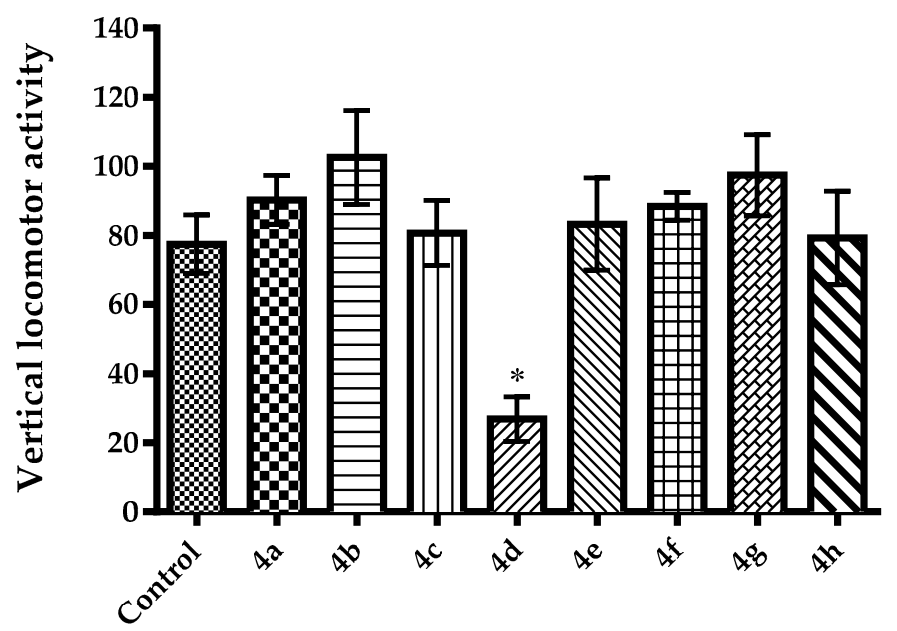

Figure 6. The effect of $\mathbf{4 a}-\mathbf{4 h}(50 \mathrm{mg} / \mathrm{kg})$ on vertical locomotor activities of animals in the activity cage test. ${ }^{*} p<0.05$, compared with control group; One way analysis of variance followed by Tukey HSD multiple comparison test, $\mathrm{n}=7$.

Following the antidepressant-like activity screening studies, we conducted some further mechanistic experiments. Instead of MFST, we conducted our studies by TST, because of the lack of hypothermia risk, enhanced pharmacological sensitivity, and rapid return to normal spontaneous activity following this test $[40,50]$.

With the aim of examining the possible involvement of the serotonergic system to the antidepressant-like effects of the compounds $\mathbf{4 a}, \mathbf{4 b}, \mathbf{4 e}$ and $\mathbf{4 f}$, we used p-chlorophenylalanine methyl ester (PCPA). PCPA is an agent inhibiting tryptophan hydroxylase enzyme playing role in the synthesis of serotonin. It stops the serotonin synthesis and reduces the endogenous serotonin storage by $60-90 \%$ in the CNS of mice, when administered at $100 \mathrm{mg} / \mathrm{kg}$ daily dose for four consecutive days. PCPA does not alter central noradrenaline or dopamine levels while reducing serotonin in brain [51-53]. In this study, effects of PCPA pre-treatments on anti-immobility activities of the compounds $\mathbf{4 a}, \mathbf{4 b}, \mathbf{4 e}$ and $\mathbf{4 f}$ in the TST were exhibited in Figure $7[\mathrm{~F}(9,60)=11.82, p<0.001]$. 


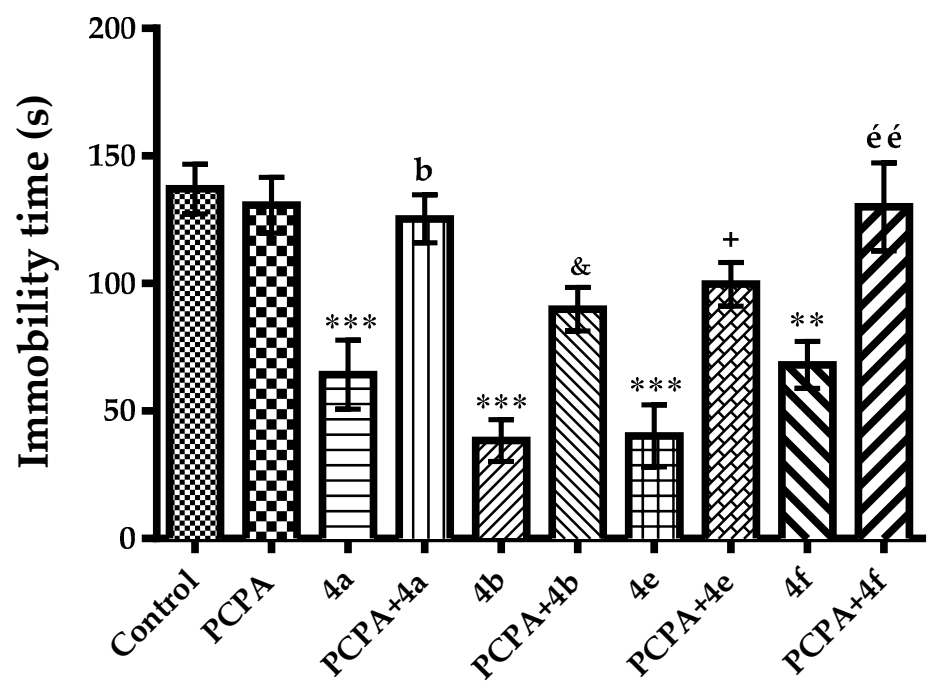

Figure 7. Effect of PCPA $(100 \mathrm{mg} / \mathrm{kg})$ pre-treatments on antidepressant-like activity induced by compounds $\mathbf{4 a}, \mathbf{4} \mathbf{b}, \mathbf{4} \mathbf{e}$ and $\mathbf{4} \mathbf{f}$ in the tail suspension test. ${ }^{* *} p<0.01,{ }^{* * *} p<0.001$, compared with control group; ${ }^{\mathrm{b}} p<0.01$, compared with compound $4 \mathrm{a}$ administrated group; ${ }^{\&} p<0.05$, compared with compound $\mathbf{4 b}$ administrated group; ${ }^{+} p<0.05$, compared with compound $4 \mathbf{e}$ administrated group; éé $p<0.01$, compared with compound $\mathbf{4 f}$ administrated group; One way analysis of variance followed by Tukey HSD multiple comparison test, $\mathrm{n}=7$.

Pre-treatments with PCPA reversed the compounds $\mathbf{4 a}, \mathbf{4 b}, \mathbf{4 e}$ and $\mathbf{4 f}$ induced shortenings in the immobility time of mice. This data indicated that antidepressant-like effects of these compounds are associated with the serotonergic neurotransmission. This result is in accordance with our experimental data obtained from the MFST tests suggesting the involvement of serotonergic system in the observed antidepressant-like effects.

After realizing the importance of serotonergic neurotransmission in the pharmacological effects of the active compounds, we tried to clarify possible serotonergic receptors participating the mechanism of action. Therefore, probable contributions of $5-\mathrm{HT}_{1 \mathrm{~A}}, 5-\mathrm{HT}_{2 \mathrm{~A} / 2 \mathrm{C}}$ and $5-\mathrm{HT}_{3}$ serotonergic receptors to the observed antidepressant-like effects were evaluated by pre-treatments with NAN-190, ketanserin and ondansetron, respectively $[54,55]$.

The effect of NAN-190 pre-treatment on anti-immobility activities of the compounds $4 \mathbf{a}, \mathbf{4} \mathbf{b}$, $4 \mathbf{e}$ and $\mathbf{4 f}$ are shown in Figure $8[\mathrm{~F}(9,60)=18.15, p<0.001]$. NAN-190 pre-treatments reversed the anti-immobility effects of these compounds pointing out the participation of $5-\mathrm{HT}_{1 \mathrm{~A}}$ receptors to the antidepressant-like effects induced by compounds $4 \mathbf{a}, \mathbf{4 b}, \mathbf{4 e}$ and $4 \mathrm{f}$.

Figure 9 displays the effect of ketanserin pre-treatment on anti-immobility activities of the compounds $4 \mathbf{a}, \mathbf{4 b}, \mathbf{4} \mathbf{e}$ and $\mathbf{4 f}[\mathrm{F}(9,60)=13.66, p<0.001]$.

Obtained data indicated that ketanserin pre-treatments antagonized the anti-immobility effects of these compounds pointing out the contribution of $5-\mathrm{HT}_{2 \mathrm{~A} / 2 \mathrm{C}}$ receptors to the exhibited antidepressant-like effects. 


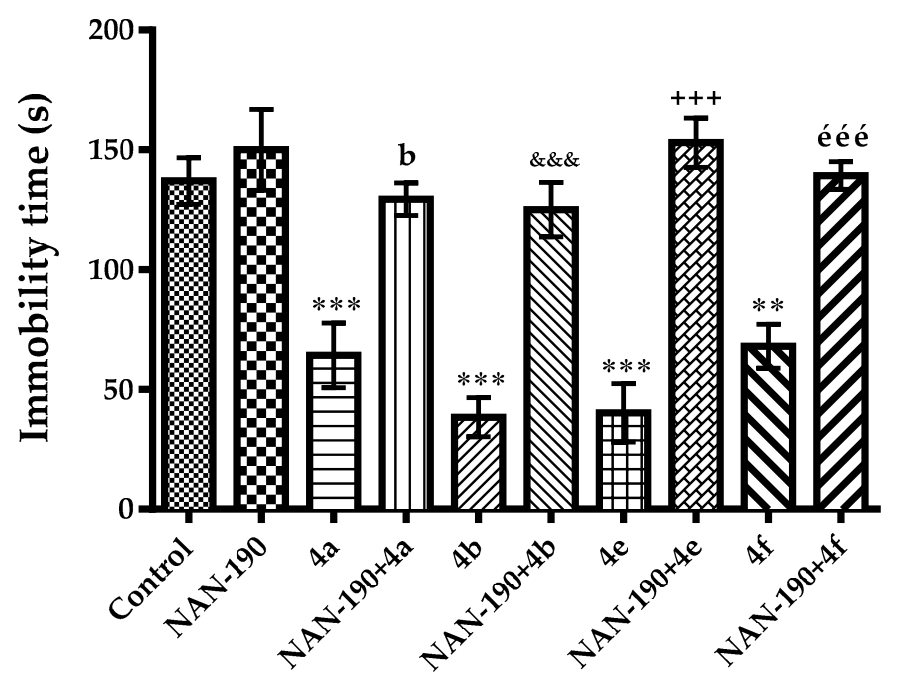

Figure 8. Effect of NAN-190 $(0.5 \mathrm{mg} / \mathrm{kg})$ pre-treatments on antidepressant-like activity induced by compounds $\mathbf{4 a}, \mathbf{4} \mathbf{b}, \mathbf{4} \mathbf{e}$ and $\mathbf{4} \mathbf{f}$ in the tail suspension test. ${ }^{* *} p<0.01,{ }^{* * *} p<0.001$, compared with control group; ${ }^{b} p<0.01$, compared with compound 4 a administrated group; \&\&\& $p<0.001$, compared with compound $4 \mathrm{~b}$ administrated group; ${ }^{+++} p<0.001$, compared with compound $4 \mathbf{e}$ administrated group; éée $p<0.001$, compared with compound $\mathbf{4 f}$ administrated group; One way analysis of variance followed by Tukey HSD multiple comparison test, $\mathrm{n}=7$.

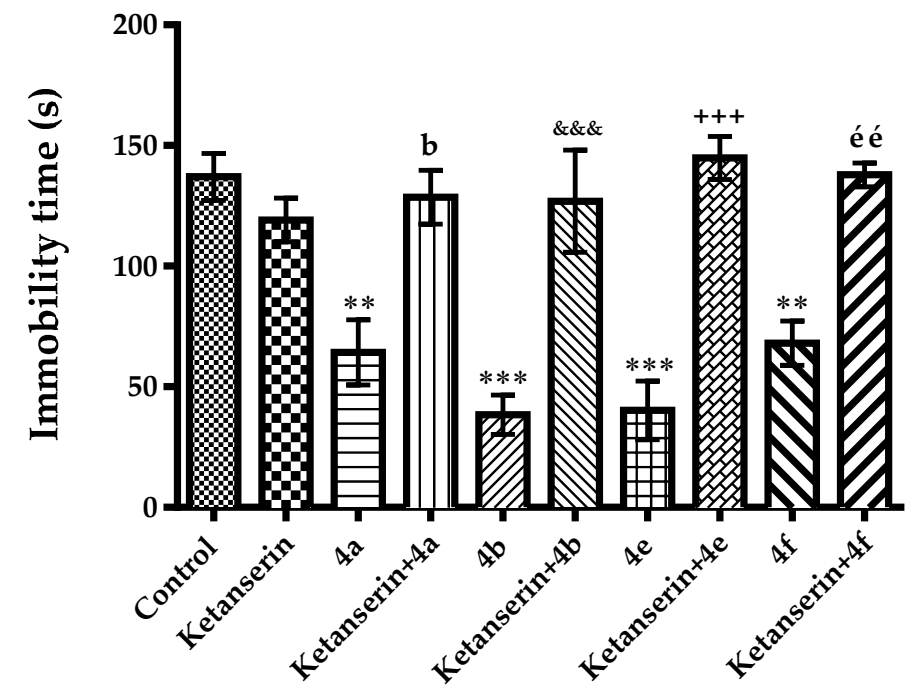

Figure 9. Effect of ketanserin $(1 \mathrm{mg} / \mathrm{kg})$ pre-treatments on antidepressant-like activity induced by compounds $\mathbf{4 a}, \mathbf{4 b}, \mathbf{4} \mathbf{e}$ and $\mathbf{4} \mathbf{f}$ in the tail suspension test. ${ }^{* *} p<0.01,{ }^{* * *} p<0.001$, compared with control group; ${ }^{b} p<0.01$, compared with compound 4 a administrated group; \&\&\& $p<0.001$, compared with compound $\mathbf{4 b}$ administrated group; ${ }^{+++} p<0.001$, compared with compound $4 \mathbf{e}$ administrated group; éé $p<0.01$, compared with compound $\mathbf{4 f}$ administrated group; One way analysis of variance followed by Tukey HSD multiple comparison test, $\mathrm{n}=7$.

The effect of ondansetron pre-treatment on anti-immobility activities of the compounds $\mathbf{4 a}, \mathbf{4 b}, \mathbf{4 e}$ and $\mathbf{4 f}$ are shown in Figure $10[\mathrm{~F}(9,60)=17.36, p<0.001]$. Ondansetron pre-treatments reversed the anti-immobility effects induced by the compounds $4 \mathbf{a}, \mathbf{4 b}, \mathbf{4 e}$ and $\mathbf{4 f}$ suggesting the involvement of $5-\mathrm{HT}_{3}$ receptors in the antidepressant-like effects of these compounds. 


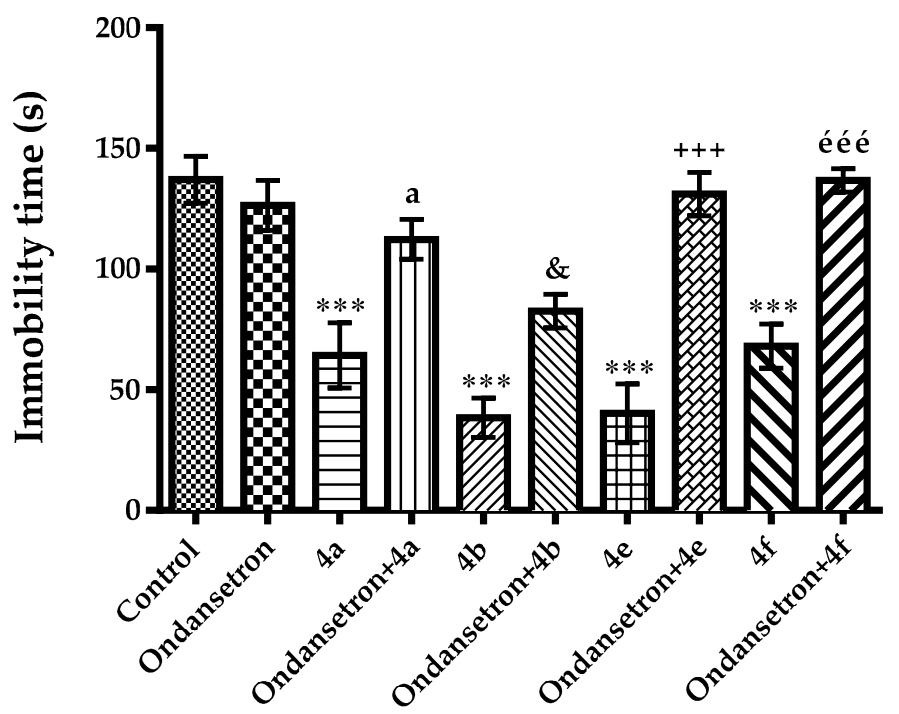

Figure 10. Effect of ondansetron $(0.3 \mathrm{mg} / \mathrm{kg})$ pre-treatments on antidepressant-like activity induced by compounds $\mathbf{4 a}, \mathbf{4 b}, \mathbf{4} \mathbf{e}$ and $\mathbf{4 f}$ in the tail suspension test. ${ }^{* *} p<0.001$, compared with control group; a $p<0.05$, compared with compound $4 \mathbf{a}$ administrated group; ${ }^{\&} p<0.05$, compared with compound $4 \mathbf{b}$ administrated group; ${ }^{++} p<0.001$, compared with compound $4 \mathbf{e}$ administrated group; éé $p<0.001$, compared with compound $\mathbf{4} \mathbf{f}$ administrated group; One way analysis of variance followed by Tukey HSD multiple comparison test, $\mathrm{n}=7$.

In summary, the findings acquired from the mechanistic studies indicated that compounds 4a, $4 \mathbf{b}, 4 \mathbf{e}$ and $\mathbf{4 f}$ presented significant antidepressant-like activities and 5- $\mathrm{HT}_{1 \mathrm{~A}}, 5-\mathrm{HT}_{2 \mathrm{~A} / 2 \mathrm{C}}$ and $5-\mathrm{HT}_{3}$ receptors seem to contribute to these effects. These results supported the previous literature pointing out the role of serotonergic system and 5- $\mathrm{HT}_{1 \mathrm{~A}}, 5-\mathrm{HT}_{2 \mathrm{~A} / 2 \mathrm{C}}$ and $5-\mathrm{HT}_{3}$ receptors [56-59] in the pharmacological mechanisms of various compounds possessing antidepressant efficacy. Actually, additional radioligand binding studies will help to confirm the involvement of these three serotonergic receptors as molecular targets of compounds $4 \mathbf{a}, \mathbf{4 b}, \mathbf{4 e}$ and $\mathbf{4 f}$. On the other hand, other serotonergic receptor subtypes might also be participated to the observed pharmacological effect. Therefore, potential involvement of additional serotonergic receptors and even other neuromediator systems (GABAergic, glutaminergic, and nitrergic systems etc.) to the presented antidepressant-like activities should also be examined by further detailed studies.

Results of the in vivo studies indicated that pharmacological activities of the compounds $4 \mathbf{a}$, $\mathbf{4 b}, \mathbf{4} \mathbf{e}$ and $\mathbf{4 f}$ (Figures 1-3) are independent of whether they contain benzimidazole (compounds $\mathbf{4 a}, \mathbf{4 b}$ ) or benzothiazole (compounds $\mathbf{4 e}, \mathbf{4 f}$ ) rings on the chemical scaffold. Instead, substitutions at the $4^{-}$-position of the piperazine ring seem to cause the difference in the activity. More specifically, antidepressant-like effect was observed with the compounds bearing methyl and ethyl groups at the piperazine 4-position (compounds $\mathbf{4 a}, \mathbf{4 b}, \mathbf{4} \mathbf{e}$ and $\mathbf{4 f}$ ), whereas isopropyl- and cyclopropyl-substituted compounds $4 \mathrm{c}, \mathbf{4 d}, \mathbf{4 g}$ and $4 \mathrm{~h}$ were found to be ineffective. Therefore, it can be suggested that steric effects may play a role on the pharmacological activity, which is enhanced by smaller substituents such as methyl and ethyl, but abolished by relatively more bulky groups like isopropyl and cyclopropyl. On the other hand, it should be noted that increasing the number of test compounds in the series might provide a more reliable approach for the structure activity relationship related to the tested compounds.

\section{Materials and Methods}

\subsection{Chemistry}

Chemicals of the Merck (Merck KGaA, Darmstadt, Germany) or Sigma-Aldrich (Sigma-Aldrich Corp., St. Louis, MO, USA) companies were used in the synthesis. The ${ }^{1} \mathrm{H}-\mathrm{NMR}$ and ${ }^{13} \mathrm{C}-\mathrm{NMR}$ spectra were recorded in DMSO- $d_{6}$ at $300 \mathrm{MHz}$ and $75 \mathrm{MHz}$, pespectively, on a digital FT-NMR 
spectrometer (Bruker Bioscience, Billerica, MA, USA). The NMR spectra signals were defined as a singlet (s), br.s. (broad singlet), doublet (d), triplet (t), double doublet (dd), and multiplet (m). The coupling constants $(J)$ are reported in units of Hertz $(\mathrm{Hz})$. A FT-IR spectrometer (IRAffinity-1S Fourier transform, Shimadzu, Tokyo, Japan) was used to record the IR spectra of the compounds. MS studies were performed on an LCMS-8040 tandem mass system (Shimadzu) and acetonitrile containing $0.1 \%$ formic acid was used as solvent. Silica gel 60 F254 by TLC (Merck KGaA) was used to monitor the progress of reactions.

\subsubsection{Synthesis of 4-Substituted Benzaldehydes 1a-1d}

A solution of 4-fluorobenzaldehyde $(0.017 \mathrm{~mol}, 1.82 \mathrm{~mL})$ and an appropriate secondary amine in DMF $(10 \mathrm{~mL})$ was refluxed $(0.017 \mathrm{~mol})$ in the presence of potassium carbonate $\left(\mathrm{K}_{2} \mathrm{CO}_{3}, 0.017 \mathrm{~mol}\right.$, $2.35 \mathrm{~g})$. After completion of reaction, the mixture was cooled with ice-water $(10 \mathrm{~mL})$ and extracted with ethyl acetate $(3 \times 20 \mathrm{~mL})$. The ethyl acetate phases were combined, and the remaining product was collected after evaporation of the solvent. The following compounds were prepared in this way: 4-(4-methylpiperazin-1-yl)benzaldehyde (1a), CAS No:27913-99-1, Yield 82\%, m.p. = 55-57 ${ }^{\circ} \mathrm{C}$ (measured), m.p. $=58-60{ }^{\circ} \mathrm{C}$ (reported) [60]; 4-(4-ethylpiperazin-1-yl)benzaldehyde (1b), CAS No:197638-76-9, Yield 79\%, obtained as an oil; 4-(4-isopropylpiperazin-1-yl)benzaldehyde (1c), CAS No:197638-78-1, Yield 84\%, obtained as an oil and 4-(4-cylopropylpiperazin-1-yl)benzaldehyde (1d), CAS No:1292778-23-4, Yield 78\%, obtained as an oil.

\subsubsection{Synthesis of Ethyl 2-(Benzazol-2-yl-thio)acetates $\mathbf{2 a}, \mathbf{2 b}$}

The corresponding benzazol-2-thiol (0.015 mol), ethyl 2-chloroacetate, (0.015 mol, $1.61 \mathrm{~mL})$, and $\mathrm{K}_{2} \mathrm{CO}_{3}(0.015 \mathrm{~mol}, 2.07 \mathrm{~g})$ were refluxed in acetone $(70 \mathrm{~mL})$ for $8-10 \mathrm{~h}$. After completion of the reaction, the solvent was removed using reduced pressure. The precipitated product was washed with water, dried and recrystallized from EtOH. The following compounds were preapared in this way: ethyl 2-(benzimidazole-2-ylthio)acetate (2a), CAS No:5429-62-9, Yield 65\%, m.p. = 99-101 ${ }^{\circ} \mathrm{C}$ (measured), m.p. $=97^{\circ} \mathrm{C}$ (reported) [61]; ethyl 2-(benzothiazol-2-ylthio)acetate (2b), CAS No:24044-88-0, Yield 72\%, m.p. $=45-47^{\circ} \mathrm{C}$ (measured), m.p. $=42-44{ }^{\circ} \mathrm{C}$ (reported) [62].

\subsubsection{Synthesis of 2-((5-Substitutedbenzazol-2-yl)thio)acetohydrazides $\mathbf{3 a}, \mathbf{3 b}$}

A solution $(20 \mathrm{~mL})$ of hydrazine hydrate $(5 \mathrm{~mL})$ in $\mathrm{EtOH}(15 \mathrm{~mL})$ was added as portions into the reaction mixture of ethyl 2-((benzazol-2-yl)thio)acetate $\mathbf{2 a - 2 b}(0.012 \mathrm{~mol})$ in $\mathrm{EtOH}$ $(50 \mathrm{~mL})$. The reaction mixture was stirred for $5 \mathrm{~h}$. The precipitated product was filtered, washed with cold-ethanol, dried and recrystallized from EtOH. To afford the following compounds: 2-((1H-benzimidazol-2-yl)thio)acetohydrazide (3a), CAS No:30065-27-1, Yield 62\%, m.p. = $164-166{ }^{\circ} \mathrm{C}$ (measured), m.p. = 165-166 ${ }^{\circ} \mathrm{C}$ (reported) [63]; 2-((1H-benzothiazole-2-yl)thio)acetohydrazide (3b), CAS No:24044-91-5, Yield 81\%, m.p. = $175-177^{\circ} \mathrm{C}$ (measured), m.p. $=173-174{ }^{\circ} \mathrm{C}$ (reported) [62].

\subsubsection{General Procedure for the Synthesis of the Target Compounds $4 \mathbf{a}-\mathbf{4 h}$}

An appropriate 2-((benzazol-2-yl)thio) acetohydrazide $3 \mathbf{a}-3 \mathbf{b}(0.002 \mathrm{~mol})$, and a 4-substitutedbenzaldehyde $\mathbf{1 a}-\mathbf{1 h}(0.002 \mathrm{~mol})$ and a catalytic amount of acetic acid were refluxed in $\mathrm{EtOH}(30 \mathrm{~mL})$ for $2 \mathrm{~h}$. The mixture was cooled in an ice-bath, and the precipitated product was filtered, dried and recrystallized from $\mathrm{EtOH}$.

2-((1H-Benzimidazol-2-yl)thio)-N'-(4-(4-methylpiperazin-1-yl)benzylidene)acetohydrazide (4a). Yield: 88\%, FTIR (ATR, cm $\left.{ }^{-1}\right): 3572(\mathrm{~N}-\mathrm{H}), 2937(\mathrm{C}-\mathrm{H}), 1660(\mathrm{C}=\mathrm{O}), 817 .{ }^{1} \mathrm{H}-\mathrm{NMR}\left(\mathrm{DMSO}-d_{6}\right): \delta=2.22(3 \mathrm{H}, \mathrm{s}$, $\left.-\mathrm{CH}_{3}\right), 2.42-2.45\left(4 \mathrm{H}, \mathrm{m}\right.$, piperazine), 3.21-3.24 (4H, m, piperazine), $3.37\left(2 \mathrm{H}, \mathrm{s},-\mathrm{CH}_{2}\right), 6.98(2 \mathrm{H}, \mathrm{d}$, $J=8.85 \mathrm{~Hz}, \mathrm{Ar}-\mathrm{H}), 7.07(1 \mathrm{H}, \mathrm{t}, J=7.80 \mathrm{~Hz}, \mathrm{Ar}-\mathrm{H}), 7.19(1 \mathrm{H}, \mathrm{t}, J=7.44 \mathrm{~Hz}, \mathrm{Ar}-\mathrm{H}), 7.32-7.37(1 \mathrm{H}, \mathrm{m}$, Ar-H), 7.48-7.56 (3H, m, Ar-H), 8.07 (1H, s, Ar-H), $11.56(1 \mathrm{H}$, br.s, $-\mathrm{NH}) .{ }^{13} \mathrm{C}-\mathrm{NMR}\left(\mathrm{DMSO}-d_{6}\right): \delta=40.82$, 
$46.20,47.65,54.90,109.68,110.66,115.04,116.72,121.49,124.52,128.31,145.45,152.24,159.99$. ESI-MS $[\mathrm{M}+\mathrm{H}]^{+}: 409.00(100 \%)$.

2-((1H-Benzimidazol-2-yl)thio)-N'-(4-(4-ethylpiperazin-1-yl)benzylidene)acetohydrazide (4b). Yield: 82\%, FTIR (ATR, cm $\left.{ }^{-1}\right): 3562(\mathrm{~N}-\mathrm{H}), 2970(\mathrm{C}-\mathrm{H}), 1660(\mathrm{C}=\mathrm{O}), 817 .{ }^{1} \mathrm{H}-\mathrm{NMR}\left(\mathrm{DMSO}-d_{6}\right): \delta=1.03(3 \mathrm{H}, \mathrm{t}$, $\left.J=7.17 \mathrm{~Hz},-\mathrm{CH}_{3}\right), 2.36\left(2 \mathrm{H}, \mathrm{q}, J=7.20 \mathrm{~Hz},-\mathrm{CH}_{2}-\right)$ 2.47-2.50 (4H, m, piperazine), 3.21-3.24 (4H, m, piperazine), $3.35\left(2 \mathrm{H}, \mathrm{s},-\mathrm{CH}_{2}\right), 6.98(2 \mathrm{H}, \mathrm{d}, J=8.85 \mathrm{~Hz}, \mathrm{Ar}-\mathrm{H}), 7.07(1 \mathrm{H}, \mathrm{t}, J=7.74 \mathrm{~Hz}, \mathrm{Ar}-\mathrm{H}), 7.19(1 \mathrm{H}, \mathrm{t}$, $J=7.50 \mathrm{~Hz}, \mathrm{Ar}-\mathrm{H}), 7.35-7.37(1 \mathrm{H}, \mathrm{m}, \mathrm{Ar}-\mathrm{H}), 7.49-7.56(3 \mathrm{H}, \mathrm{m}, \mathrm{Ar}-\mathrm{H}), 8.07$ (1H, s, Ar-H), 11.80 (1H, br.s, -NH). ${ }^{13}$ C-NMR (DMSO-d ${ }_{6}$ ): $\delta=12.45,40.89,47.76,52.08,52.67,109.67,114.99,116.71,121.48,124.52$, $128.29,142.94,145.47,148.55,152.27,160.00$. ESI-MS $[\mathrm{M}+\mathrm{H}]^{+}: 423.10(100 \%)$.

2-((1H-Benzimidazol-2-yl)thio)-N'-(4-(4-isopropylpiperazin-1-yl)benzylidene)acetohydrazide (4c). Yield: 80\%, FTIR (ATR, cm ${ }^{-1}$ ): $3562(\mathrm{~N}-\mathrm{H}), 2966(\mathrm{C}-\mathrm{H}), 1708(\mathrm{C}=\mathrm{O}), 806 .{ }^{1} \mathrm{H}-\mathrm{NMR}\left(\mathrm{DMSO}-d_{6}\right): \delta=0.99(6 \mathrm{H}, \mathrm{d}$, $\left.J=6.45 \mathrm{~Hz},-\mathrm{CH}_{3}\right), 2.55$ (4H, br.s., piperazine), 2.62-2.69 (1H, m, $\left.-\mathrm{CH}-\right), 3.21(4 \mathrm{H}$, br.s., piperazine), 4.64 $\left(2 \mathrm{H}, \mathrm{s},-\mathrm{CH}_{2}-\right), 6.95(2 \mathrm{H}, \mathrm{d}, J=8.85 \mathrm{~Hz}, \mathrm{Ar}-\mathrm{H}), 7.31-7.34(2 \mathrm{H}, \mathrm{m}, \mathrm{Ar}-\mathrm{H}), 7.53(2 \mathrm{H}, \mathrm{d}, J=8.76 \mathrm{~Hz}, \mathrm{Ar}-\mathrm{H})$, 7.63-7.66 (2H, m, Ar-H), $7.93(1 \mathrm{H}, \mathrm{s}, \mathrm{Ar}-\mathrm{H}), 11.58(1 \mathrm{H}, \mathrm{s},-\mathrm{NH}) .{ }^{13} \mathrm{C}-\mathrm{NMR}\left(\mathrm{DMSO}-d_{6}\right): \delta=18.67,35.26$, $48.08,48.38,54.12,110.67,114.90,118.72,124.04,124.71,125.09,128.58,141.73,144.94,148.04,152.61$, 162.74, 167.97. ESI-MS $[\mathrm{M}+\mathrm{H}]^{+}: 437.20(100 \%)$.

2-((1H-Benzimidazol-2-yl)thio)-N'-(4-(4-cyclopropylpiperazin-1-yl)benzylidene)acetohydrazide (4d). Yield: 79\%, FTIR (ATR, cm ${ }^{-1}$ ): $3550(\mathrm{~N}-\mathrm{H}), 2974(\mathrm{C}-\mathrm{H}), 1718(\mathrm{C}=\mathrm{O}), 810 .{ }^{1} \mathrm{H}-\mathrm{NMR}\left(\mathrm{DMSO}-d_{6}\right): \delta=0.34-0.35$ $\left(2 \mathrm{H}, \mathrm{m},-\mathrm{CH}_{2}-\right), 0.42-0.44\left(2 \mathrm{H}, \mathrm{m},-\mathrm{CH}_{2}-\right), 1.62-1.65(1 \mathrm{H}, \mathrm{m},-\mathrm{CH}-), 2.65$ (4H, br.s., piperazine), 3.17-3.20 (4H, m, piperazine), $4.65\left(2 \mathrm{H}, \mathrm{s},-\mathrm{CH}_{2}-\right), 6.93-6.98(2 \mathrm{H}, \mathrm{m}, \mathrm{Ar}-\mathrm{H}), 7.07(1 \mathrm{H}, \mathrm{t}, J=7.86 \mathrm{~Hz}, \mathrm{Ar}-\mathrm{H}), 7.19$ $(1 \mathrm{H}, \mathrm{t}, J=6.81, \mathrm{Ar}-\mathrm{H})$ 7.31-7.33 (1H, m), 7.51-7.57 (2H, m, Ar-H), 7.63-7.65 (1H, m, Ar-H), 11.59 (1H, s, -NH). ${ }^{13}$ C-NMR (DMSO- $\left.d_{6}\right): \delta=6.09,35.27,38.52,47.78,52.99,53.04,110.66,115.07,118.72,121.46$, $124.71,125.09,128.58,141.73,144.92,148.01,152.25,162.76,167.97$. ESI-MS [M + H] $]^{+} 435.20(100 \%)$.

2-(Benzothiazol-2-ylthio)-N'-(4-(4-methylpiperazin-1-yl)benzylidene)acetohydrazide (4e). Yield: 81\%, FTIR (ATR, cm ${ }^{-1}$ ): $3313(\mathrm{~N}-\mathrm{H}), 2933(\mathrm{C}-\mathrm{H}), 1660(\mathrm{C}=\mathrm{O}), 819 .{ }^{1} \mathrm{H}-\mathrm{NMR}\left(\mathrm{DMSO}-d_{6}\right): \delta=2.22\left(3 \mathrm{H}, \mathrm{s},-\mathrm{CH}_{3}\right)$, 2.42-2.43 (4H, m, piperazine), 3.21-3.24 (4H, m, piperazine), $4.66\left(2 \mathrm{H}, \mathrm{s},-\mathrm{CH}_{2}\right), 6.96(2 \mathrm{H}, \mathrm{t}, J=9.63$ $\mathrm{Hz}, \mathrm{Ar}-\mathrm{H}), 7.34-7.40$ (1H, m, Ar-H), 7.44-7.55 (3H, m, Ar-H), 7.85 (1H, d, J = 8.07 Hz, Ar-H), 7.93 (1H, s, Ar-H), 8.00-8.04 (1H, m, Ar-H), 11.54 (1H, s, -NH). ${ }^{13} \mathrm{C}-\mathrm{NMR}\left(\mathrm{DMSO}-d_{6}\right): \delta=35.61,46.20,47.57$, 54.85, 114.98, 121.58, 122.30, 124.17, 124.92, 126.84, 128.56, 135.20, 144.74, 147.99, 152.49, 162.98, 168.29 . ESI-MS $[\mathrm{M}+\mathrm{H}]^{+}: 426.10(100 \%)$.

2-(Benzothiazol-2-ylthio)-N'-(4-(4-ethylpiperazin-1-yl)benzylidene)acetohydrazide (4f). Yield: 82\%, FTIR $\left(\mathrm{ATR}, \mathrm{cm}^{-1}\right)$ : $3228(\mathrm{~N}-\mathrm{H}), 2966(\mathrm{C}-\mathrm{H}), 1662(\mathrm{C}=\mathrm{O}), 821 .{ }^{1} \mathrm{H}-\mathrm{NMR}\left(\mathrm{DMSO}-d_{6}\right): \delta=1.02(3 \mathrm{H}, \mathrm{t}, \mathrm{J}=6.63$ $\left.\mathrm{Hz},-\mathrm{CH}_{3}\right), 2.34(2 \mathrm{H}, \mathrm{q}, J=7.32 \mathrm{~Hz}), 2.46$ (4H, br.s., piperazine), 3.21 (4H, br.s., piperazine), $4.64(2 \mathrm{H}, \mathrm{s}$, $\left.-\mathrm{CH}_{2}-\right), 6.94(2 \mathrm{H}, \mathrm{d}, \mathrm{J}=8.73 \mathrm{~Hz}, \mathrm{Ar}-\mathrm{H}), 7.35(1 \mathrm{H}, \mathrm{m}, \mathrm{Ar}-\mathrm{H}), 7.43-7.51(3 \mathrm{H}, \mathrm{m}, \mathrm{Ar}-\mathrm{H}), 7.84(1 \mathrm{H}, \mathrm{d}, J=7.92$ $\mathrm{Hz}, \mathrm{Ar}-\mathrm{H}), 7.91(1 \mathrm{H}, \mathrm{s}, \mathrm{Ar}-\mathrm{H}), 8.01(1 \mathrm{H}, \mathrm{d}, J=8.67 \mathrm{~Hz}, \mathrm{Ar}-\mathrm{H}), 11.52(1 \mathrm{H}, \mathrm{s},-\mathrm{NH}) .{ }^{13} \mathrm{C}-\mathrm{NMR}\left(\mathrm{DMSO}-d_{6}\right)$ : $\delta=17.18,40.35,52.43,56.82,57.37,119.68,126.33,127.05,128.91,129.67,131.60,133.31,139.95,149.50$, $152.75,157.27,167.73,173.04$. ESI-MS $[\mathrm{M}+\mathrm{H}]^{+}: 440.11(100 \%)$.

2-(Benzothiazol-2-ylthio)-N'-(4-(4-isopropylpiperazin-1-yl)benzylidene)acetohydrazide (4g). Yield: 82\%, FTIR $\left(\right.$ ATR, $\left.\mathrm{cm}^{-1}\right): 3471(\mathrm{~N}-\mathrm{H}), 2960(\mathrm{C}-\mathrm{H}), 1668(\mathrm{C}=\mathrm{O}), 833 .{ }^{1} \mathrm{H}-\mathrm{NMR}\left(\mathrm{DMSO}-d_{6}\right): \delta=0.99(6 \mathrm{H}, \mathrm{d}, J=6.51$ $\left.\mathrm{Hz},-\mathrm{CH}_{3}\right), 2.50-2.51$ (1H, m, $\left.-\mathrm{CH}-\right), 2.54-2.57$ (4H, m, piperazine), 3.19-3.22 (4H, m, piperazine), 4.66 $\left(2 \mathrm{H}, \mathrm{s},-\mathrm{CH}_{2}-\right), 6.94(2 \mathrm{H}, \mathrm{t}, J=9.67 \mathrm{~Hz}, \mathrm{Ar}-\mathrm{H}), 7.34-7.40(1 \mathrm{H}, \mathrm{m}, \mathrm{Ar}-\mathrm{H}), 7.44-7.47(1 \mathrm{H}, \mathrm{m}, \mathrm{Ar}-\mathrm{H}), 7.51$ $(1 \mathrm{H}, \mathrm{d}, J=6.30 \mathrm{~Hz}, \mathrm{Ar}-\mathrm{H}), 7.54(1 \mathrm{H}, \mathrm{d}, J=6.12 \mathrm{~Hz}, \mathrm{Ar}-\mathrm{H}), 7.84-7.89$ (1H, m, Ar-H), 7.93 (1H, s, Ar-H), 8.00-8.04 (1H, m, Ar-H), $11.53(1 \mathrm{H}, \mathrm{s},-\mathrm{NH}) .{ }^{13} \mathrm{C}-\mathrm{NMR}\left(\mathrm{DMSO}-d_{6}\right): \delta=18.66,35.60,48.07,48.37,54.13$, $114.89,121.58,122.30,124.09,124.92,126.84,128.55,128.85,135.20,144.76,148.02,152.57,162.97,168.29$. ESI-MS [M + H] $]^{+}: 454.13(100 \%)$. 
2-(Benzothiazol-2-ylthio)-N'-(4-(4-cyclopropylpiperazin-1-yl)benzylidene)acetohydrazide (4h). Yield: 82\%, FTIR (ATR, $\left.\mathrm{cm}^{-1}\right): 3228(\mathrm{~N}-\mathrm{H}), 2821(\mathrm{C}-\mathrm{H}), 1654(\mathrm{C}=\mathrm{O}), 821 .{ }^{1} \mathrm{H}-\mathrm{NMR}\left(\mathrm{DMSO}-d_{6}\right): \delta=0.34-0.36(2 \mathrm{H}, \mathrm{m}$, $\left.-\mathrm{CH}_{2}-\right), 0.41-0.44\left(2 \mathrm{H}, \mathrm{m},-\mathrm{CH}_{2}-\right), 1.62-1.66(1 \mathrm{H}, \mathrm{m},-\mathrm{CH}-), 2.63-2.65(4 \mathrm{H}, \mathrm{m}$, piperazine $), 3.16-3.19(4 \mathrm{H}$, $\mathrm{m}$, piperazine), $4.65\left(2 \mathrm{H}, \mathrm{s},-\mathrm{CH}_{2}-\right), 6.94(2 \mathrm{H}, \mathrm{t}, J=9.46 \mathrm{~Hz}, \mathrm{Ar}-\mathrm{H}), 7.34-7.39(1 \mathrm{H}, \mathrm{m}, \mathrm{Ar}-\mathrm{H}), 7.44-7.47$ $(1 \mathrm{H}, \mathrm{m}, \mathrm{Ar}-\mathrm{H}), 7.50(1 \mathrm{H}, \mathrm{d}, J=6.24 \mathrm{~Hz}, \mathrm{Ar}-\mathrm{H}), 7.53(1 \mathrm{H}, \mathrm{d}, J=5.94 \mathrm{~Hz}, \mathrm{Ar}-\mathrm{H}), 7.85(1 \mathrm{H}, \mathrm{d}, J=8.10 \mathrm{~Hz}$, Ar-H), $7.92(1 \mathrm{H}, \mathrm{s}, \mathrm{Ar}-\mathrm{H}), 7.99-8.03(1 \mathrm{H}, \mathrm{m}, \mathrm{Ar}-\mathrm{H}), 11.53(1 \mathrm{H}, \mathrm{s},-\mathrm{NH}) .{ }^{13} \mathrm{C}-\mathrm{NMR}$ (DMSO-d $\left.d_{6}\right): \delta=6.08$, 35.61, 47.61, 47.70, 52.99, 115.01, 121.58, 122.29, 124.16, 124.92, 126.84, 128.56, 135.20, 144.73, 147.98, 152.51, 162.97, 168.29. ESI-MS [M + H] ${ }^{+}: 452.12(100 \%)$.

\subsection{Pharmacology}

\subsubsection{Animals}

Adult Balb/c mice weighing 30-35 g were used for the behavioral tests. They were group-housed and maintained in standard laboratory conditions: constant temperature $\left(24 \pm 1{ }^{\circ} \mathrm{C}\right)$ and $12-\mathrm{h}$ light/dark cycle. Animals were allowed to acclimatize to the laboratory conditions $48 \mathrm{~h}$ before the experiments. The experimental protocol of this study was approved by the Local Ethical Committee on Animal Experimentation of Anadolu University (Eskişehir, Turkey; date: 13.04.2018; Project no: 2018-21).

\subsubsection{Experimental Groups and Treatments}

Animals were randomly placed into 10 groups with seven animals in each. Efficacies of the test compounds (50 mg/kg, po) [21] were compared to control and fluoxetine (reference drug, $20 \mathrm{mg} / \mathrm{kg}$, po) groups [37]. Vehicle, fluoxetine and test compounds were administered three times to mice at 24,5 and $1.0 \mathrm{~h}$ before the experiments $[37,64]$.

\subsubsection{Evaluation of Antidepressant-Like Activity}

Tail Suspension Test

TST was carried out as previously described [36,41]. In this test, mice were suspended $30 \mathrm{~cm}$ above the ground with an adhesive tape, which is located about one $\mathrm{cm}$ from tip of the tails. Animals were evaluated as immobile when they did not perform escape-oriented movements and become motionless. Total duration of the immobility behavior was measured by a chronometer over the last 4 min of the 6-min test period. Mice climbing their tails during the tests were eliminated from the tests.

Modified Forced Swimming Test

MFST was also performed to examine the antidepressant-like effects of test compounds. In this test, mice were forced to swim in a Plexiglas cylinder ( $30 \mathrm{~cm}$ height, $12 \mathrm{~cm}$ diameter) filled with water up to $20 \mathrm{~cm}$ high. The temperature of the water was set at $25 \pm 1{ }^{\circ} \mathrm{C}$. Twenty-four hours before the experiments, animals were let to swim individually in the cylinder for $15 \mathrm{~min}$. In the experimental phase, mice were placed again in the cylinder and durations of immobility (the movements required to keep the head above the water), swimming (horizontal motion on the surface of the water) and climbing (upward-directed movements of the forepaws along the side of the swim chamber) behaviors over 5-s intervals were measured with a chronometer for 5 min $[36,47,65]$.

The water in the cylinder was changed after each mouse. After pre-test and experimental phases, mice were dried carefully before returning their home cages. 


\subsubsection{Evaluation of Spontaneous Locomotor Activity}

Activity Cage Test

Activity cage device (No. 7420, Ugo Basile, Varese, Italy) was used to assess the effects of test compounds on motor activities of mice. In this device, numbers of movements interrupting the IR beams are recorded, automatically. Horizontal and vertical spontaneous locomotor activities were recorded for $4 \mathrm{~min}$. After testing each animal, the apparatus was carefully cleaned with ethanol solution $[37,66]$.

\section{Mechanistic Studies}

Mechanistic studies were performed with PCPA (a serotonin synthesis inhibitor), NAN-190 $\left(5-\mathrm{HT}_{1 \mathrm{~A}}\right.$ receptor antagonist), ketanserin $\left(5-\mathrm{HT}_{2 \mathrm{~A} / 2 \mathrm{C}}\right.$ receptor antagonist) and ondansetron $\left(5-\mathrm{HT}_{3}\right.$ receptor antagonist) to investigate the possible involvement of the serotonergic system and serotonergic receptors in the antidepressant-like effects of test compounds. PCPA was intraperitoneally administered at dose of $100 \mathrm{mg} / \mathrm{kg}$ for four consecutive days. Test compounds were applied $24 \mathrm{~h}$ after the last injection and $1 \mathrm{~h}$ later, animals were subjected to the TST [54]. NAN-190 (0.5 mg/ $\mathrm{kg}$ i.p.), ketanserin ( $1 \mathrm{mg} / \mathrm{kg}$ i.p.), ondansetron $(0.3 \mathrm{mg} / \mathrm{kg}$ i.p.) were injected $15 \mathrm{~min}$ prior to the administration of the test compounds. Then, TST was conducted $1 \mathrm{~h}$ later [36].

\section{Statistical Analysis}

Graphpad Prism ver. 6.01 (GraphPad Software, San Diego, CA, USA) was used for statistical analyses and for the preparation of graphical presentations. Obtained data was analyzed using one-way analysis of variance (ANOVA) followed by Tukey's multiple comparisons test. Results were expressed as the mean \pm standard error of the mean (SEM). Differences between the groups were considered as statistically significant if $p<0.05$.

\section{Conclusions}

Data obtained from this study presented that test compounds $4 \mathrm{a}, 4 \mathrm{~b}, \mathbf{4 e}$ and $\mathbf{4 f}$ possess significant antidepressant-like efficacy mediated through serotonergic system and 5- $\mathrm{HT}_{1 \mathrm{~A}}, 5-\mathrm{HT}_{2 \mathrm{~A} / 2 \mathrm{C}} 5-\mathrm{HT}_{3}$ serotonergic receptors. These results supported to the previous literature findings pointing out the antidepressant capacity of benzazole derivative compounds [20-22,26,27]. On the other hand, to clarify the exact mechanism of action possible contribution of other neurotransmitter systems (such as opioidergic, GABAergic, glutaminergic, and nitrergic systems) should also be investigated by further studies.

Supplementary Materials: The ${ }^{13} \mathrm{C}-\mathrm{NMR},{ }^{1} \mathrm{H}-\mathrm{NMR}$, FTIR, and MS spectrums of compounds $4 \mathrm{a}-4 \mathrm{~h}$ are available online.

Author Contributions: Conceptualization and design of the study, Ü.D.Ö. and Z.A.K.; Synthesis of the compounds: Z.A.K. and D.O., Conducting pharmacological tests G.T. and N.T.Y.; Statistical analysis of the data Ü.D.Ö. and Ö.D.C.; Writing of the manuscript Ü.D.Ö. and Ö.D.C.; Proofreading Z.A.K.

Acknowledgments: This research was supported from the Anadolu University Scientific Research Projects Commission (Project No: 1805S189).

Conflicts of Interest: The authors declare no conflict of interest.

\section{References}

1. WHO, mhGAP Intervention Guide for Mental, Neurological and Substance Use Disorders in Non-Specialized Health Settings. 2010. Available online: http://apps.who.int/iris/bitstream/10665/ 44406/1/9789241548069_eng.pdf (accessed on 1 May 2018). 
2. WHO, DEPRESSION: A Global Crisis World Mental Health Day. 2012. Available online: http://www. who.int/mental_health/management/depression/wfmh_paper_depression_wmhd_2012.pdf (accessed on 1 May 2018).

3. Paschos, K.A.; Veletza, S.; Chatzaki, E. Neuropeptide and sigma receptors as novel therapeutic targets for the pharmacotherapy of depression. CNS Drugs 2009, 23, 755-772. [CrossRef] [PubMed]

4. Yue, N.; Li, B.; Yang, L.; Han, Q.Q.; Huang, H.J.; Wang, Y.L.; Wang, J.; Yu, R.; Wu, G.C.; Liu, Q.; et al. Electro-Acupuncture Alleviates Chronic Unpredictable Stress-Induced Depressive- and Anxiety-Like Behavior and Hippocampal Neuroinflammation in Rat Model of Depression. Front. Mol. Neurosci. 2018. [CrossRef] [PubMed]

5. Ajani, O.O.; Tolu-Bolaji, O.O.; Olorunshola, S.J.; Zhao, Y.; Aderohunmu, D.V. Structure-based design of functionalized 2-substituted and 1,2-disubstituted benzimidazole derivatives and their in vitro antibacterial efficacy. J. Adv. Res. 2017, 8, 703-712. [CrossRef] [PubMed]

6. Ibrahim, H.A.; Awadallah, F.M.; Refaat, H.M.; Amin, K.M. Molecular docking simulation, synthesis and 3D pharmacophore studies of novel 2-substituted-5-nitro-benzimidazole derivatives as anticancer agents targeting VEGFR-2 and c-Met. Bioorg. Chem. 2018, 77, 457-470. [CrossRef] [PubMed]

7. Singh, A.; Yadav, D.; Yadav, M.; Dhamanage, A.; Kulkarni, S.; Singh, R.K. Molecular modeling, synthesis and biological evaluation of N-heteroaryl compounds as reverse transcriptase inhibitors against HIV-1. Chem. Biol. Drug Des. 2015, 85, 336-347. [CrossRef] [PubMed]

8. Noor, A.; Qazi, N.G.; Nadeem, H.; Khan, A.U.; Paracha, R.Z.; Ali, F.; Saeed, A. Synthesis, characterization, anti-ulcer action and molecular docking evaluation of novel benzimidazole-pyrazole hybrids. Chem. Cent. J. 2017, 11, 85. [CrossRef] [PubMed]

9. Vaidya, S.D.; Kumar, B.V.S.; Kumar, R.V.; Bhise, U.N.; Mashelkar, U.C. Synthesis, anti-bacterial, anti-asthmatic and anti-diabetic activities of novel N-substituted-2-(benzo[d]isoxazol-3-ylmethyl)-1H-benzimidazoles. J. Heterocycl. Chem. 2007, 44, 685-691. [CrossRef]

10. Shingalapur, R.V.; Hosamani, K.M.; Keri, R.S.; Hugar, M.H. Derivatives of benzimidazole pharmacophore: Synthesis, anticonvulsant, antidiabetic and DNA cleavage studies. Eur. J. Med. Chem. 2010, 45, 1753-1759. [CrossRef] [PubMed]

11. Shaikh, I.N.; Hosamani, K.M.; Seetharamareddy, H.R.; Hugar, M.H. Synthesis and in-vivo evaluation of carbonyl-amide linkage based new benzimidazole derivatives. Arch. Pharm. 2012, 345, 65-72. [CrossRef] [PubMed]

12. Zhu, W.; Da, Y.; Wu, D.; Zheng, H.; Zhu, L.; Wang, L.; Yan, Y.; Chen, Z. Design, synthesis and biological evaluation of new 5-nitro benzimidazole derivatives as AT1 antagonists with anti-hypertension activities. Bioorg. Med. Chem. 2014, 22, 2294-2302. [CrossRef] [PubMed]

13. Alpan, A.S.; Sarıkaya, G.; Çoban, G.; Parlar, S.; Armagan, G.; Alptüzün, V. Mannich-Benzimidazole Derivatives as Antioxidant and Anticholinesterase Inhibitors: Synthesis, Biological Evaluations, and Molecular Docking Study. Arch. Pharm. 2017. [CrossRef] [PubMed]

14. Lad, N.P.; Manohar, Y.; Mascarenhas, M.; Pandit, Y.B.; Kulkarni, M.R.; Sharma, R.; Salkar, K.; Suthar, A.; Pandit, S.S. Methylsulfonyl benzothiazoles (MSBT) derivatives: Search for new potential antimicrobial and anticancer agents. Bioorg. Med. Chem. Lett. 2017, 27, 1319-1324. [CrossRef] [PubMed]

15. Karali, N.; Güzel, O.; Ozsoy, N.; Ozbey, S.; Salman, A. Synthesis of new spiroindolinones incorporating a benzothiazole moiety as antioxidant agents. Eur. J. Med. Chem. 2010, 45, 1068-1077. [CrossRef] [PubMed]

16. Akhtar, M.J.; Khan, A.A.; Ali, Z.; Dewangan, R.P.; Rafi, M.; Hassan, M.Q.; Akhtar, M.S.; Siddiqui, A.A.; Partap, S.; Pasha, S.; et al. Synthesis of stable benzimidazole derivatives bearing pyrazole as anticancer and EGFR receptor inhibitors. Bioorg. Chem. 2018, 78, 158-169. [CrossRef] [PubMed]

17. Netalkar, P.P.; Netalkar, S.P.; Budagumpi, S.; Revankar, V.K. Synthesis, crystal structures and characterization of late first row transition metal complexes derived from benzothiazole core: Anti-tuberculosis activity and special emphasis on DNA binding and cleavage property. Eur. J. Med. Chem. 2014, 79, 47-56. [CrossRef] [PubMed]

18. Meltzer-Mats, E.; Babai-Shani, G.; Pasternak, L.; Uritsky, N.; Getter, T.; Viskind, O.; Eckel, J.; Cerasi, E.; Senderowitz, H.; Sasson, S.; et al. Synthesis and mechanism of hypoglycemic activity of benzothiazole derivatives. J. Med. Chem. 2013, 56, 5335-5350. [CrossRef] [PubMed] 
19. Azam, M.A.; Dharanya, L.; Mehta, C.C.; Sachdeva, S. Synthesis and biological evaluation of some novel pyrazolopyrimidines incorporating a benzothiazole ring system. Acta Pharm. 2013, 63, 19-30. [CrossRef] [PubMed]

20. Mute, V.M.; Bodhankar, S.L. Antidepressant like effect of newly synthesized compound 2[(N-benzylacetamido) mercapto] benzimidazole (vs 25) and its possible mechanism by inhibition of monoamine oxidase enzyme in mice. Int. J. Pharm. Pharm. Sci. 2015, 7, 407-410.

21. Khan, I.; Tantray, M.A.; Hamid, H.; Alam, M.S.; Kalam, A.; Dhulap, A. Synthesis of benzimidazole based thiadiazole and carbohydrazide conjugates as glycogen synthase kinase- $3 \beta$ inhibitors with anti-depressant activity. Bioorg. Med. Chem. Lett. 2016, 26, 4020-4024. [CrossRef] [PubMed]

22. Tantray, M.A.; Khan, I.; Hamid, H.; Alam, M.S.; Dhulap, A.; Kalam, A. Synthesis of benzimidazole-based 1,3,4-oxadiazole-1,2,3-triazole conjugates as glycogen synthase kinase-3b inhibitors with antidepressant activity in in vivo models. SC Adv. 2016, 6, 43345-43355.

23. Kamil, A.; Akhtar, S.; Khan, A.; Farooq, E.; Nishan, U.; Uddin, R.; Farooq, U. Synthesis, structure-activity relationship and antinociceptive activities of some 2-(2'-pyridyl) benzimidazole derivatives. Med. Chem. Res. 2016, 25, 1216-1228. [CrossRef]

24. Palin, R.; Clark, J.K.; Evans, L.; Houghton, A.K.; Jones, P.S.; Prosser, A.; Wishart, G.; Yoshiizumi, K. Structure-activity relationships and CoMFA of N-3 substituted phenoxypropyl piperidine benzimidazol-2-one analogues as NOP receptor agonists with analgesic properties. Bioorg. Med. Chem. 2008, 16, 2829-2851. [CrossRef] [PubMed]

25. Jain, P.; Sharma, P.K.; Rajak, H.; Pawar, R.S.; Patil, U.K.; Singour, P.K. Design, synthesis and biological evaluation of some novel benzimidazole derivatives for their potential anticonvulsant activity. Arch. Pharm. Res. 2010, 33, 971-980. [CrossRef] [PubMed]

26. Siddiqui, N.; Rana, A.; Khan, S.A.; Ahsan, W.; Alam, M.S.; Ahmed, S. Analgesic and antidepressant activities of benzothiazole-benzamides. Biomed. Pharmacol. J. 2008, 1, 297-300.

27. Wang, S.; Chen, Y.; Zhao, S.; Xu, X.; Liu, X.; Liu, B.F.; Zhang, G. Synthesis and biological evaluation of a series of benzoxazole/benzothiazole-containing 2,3-dihydrobenzo[b][1,4]dioxine derivatives as potential antidepressants. Bioorg. Med. Chem. Lett. 2014, 24, 1766-1770. [CrossRef] [PubMed]

28. Ali, R.; Siddiqui, N. New benzo[d]thiazol-2-yl-aminoacetamides as potential anticonvulsants: Synthesis, activity and prediction of molecular properties. Arch. Pharm. 2015, 348, 254-265. [CrossRef] [PubMed]

29. Liu, D.C.; Zhang, H.J.; Jin, C.M.; Quan, Z.S. Synthesis and biological evaluation of novel benzothiazole derivatives as potential anticonvulsant agents. Molecules 2016, 21, 164. [CrossRef] [PubMed]

30. Kaplancikli, Z.A.; Altintop, M.D.; Turan-Zitouni, G.; Ozdemir, A.; Can, O.D. Synthesis and analgesic activity of some acetamide derivatives. J. Enzyme Inhib. Med. Chem. 2012, 27, 275-280. [CrossRef] [PubMed]

31. Hamdy, N.A.; Abdel-Aziz, H.A.; Kamel, G.M.; Fakhr, I.M. Convenient synthesis, anti-inflammatory, analgesic and ulcerogenic activites of some new bis-hydrazones and pyrazole derivatives. Acta Pol. Pharm. 2013, 70, 469-480. [PubMed]

32. Gökce, M.I.; Cakir, B.; Erol, K.; Sahin, M.F. Synthesis and antinociceptive activity of [(2-oxobenzothiazolin-3-yl)methyl]-4-alkyl/aryl-1,2,4-triazoline-5-thiones. Arch. Pharm. 2001, 334, 279-283. [CrossRef]

33. Ozkay, U.D.; Can, O.D.; Özkay, Y.; Öztürk, Y. Effect of benzothiazole/piperazine derivatives on intracerebroventricular streptozotocin-induced cognitive deficits. Pharmacol. Rep. 2012, 64, 834-847. [CrossRef]

34. Keri, R.S.; Quintanova, C.; Marques, S.M.; Esteves, A.R.; Cardoso, S.M.; Santos, M.A. Design, synthesis and neuroprotective evaluation of novel tacrine-benzothiazole hybrids as multi-targeted compounds against Alzheimer's disease. Bioorg. Med. Chem. 2013, 21, 4559-4569. [CrossRef] [PubMed]

35. Carboni, S.; Hiver, A.; Szyndralewiez, C.; Gaillard, P.; Gotteland, J.P.; Vitte, P.A. AS601245 (1,3-benzothiazol-2 -yl(2-[[2-(3-pyridinyl)ethyl]amino]-4-pyrimidinyl)acetonitrile): A c-Jun NH2-terminal protein kinase inhibitor with neuroprotective properties. J. Pharmacol. Exp. Ther. 2004, 310, 25-32. [CrossRef] [PubMed]

36. Can, Ö.D.; Turan, N.; Demir Özkay, Ü.; Öztürk, Y. Antidepressant-like effect of gallic acid in mice: Dual involvement of serotonergic and catecholaminergic systems. Life Sci. 2017, 190, 110-117. [CrossRef] [PubMed]

37. Demir Özkay, Ü.; Yurttas, L.; Özkay, Y.; Üçel, U.I.; Can, Ö.D.; Öztürk, Y. Synthesis of new 1-phenyl-2(4-substituted-piperazin-1-yl)-propanol derivatives and evaluation of their antidepressant-like effects. Arch. Pharm. Res. 2013, 36, 802-811. [CrossRef] [PubMed] 
38. Can, A.; Dao, D.T.; Terrillion, C.E.; Piantadosi, S.C.; Bhat, S.; Gould, T.D. The tail suspension test. J. Vis. Exp. 2012. [CrossRef] [PubMed]

39. Slattery, D.A.; Cryan, J.F. Using the rat forced swim test to assess antidepressant-like activity in rodents. Nat. Protoc. 2012, 7, 1009-1014. [CrossRef] [PubMed]

40. Cryan, J.F.; Mombereau, C.; Vassout, A. The tail suspension test for assessing antidepressant activity: Review of pharmacological and genetic studies in mice. Neurosci. Biobehav. Rev. 2005, 29, 571-625. [CrossRef] [PubMed]

41. Steru, L.; Chermat, R.; Thierry, B.; Simon, P. The tail suspension test: A new method for screening antidepressants in mice. Psychopharmacology 1985, 85, 367-370. [CrossRef] [PubMed]

42. Brocardo, P.S.; Budni, J.; Kaster, M.P.; Santos, A.R.; Rodrigues, A.L. Folic acid administration produces an antidepressant-like effect in mice: Evidence for the involvement of the serotonergic and noradrenergic systems. Neuropharmacology 2008, 54, 464-473. [CrossRef] [PubMed]

43. Girish, C.; Raj, V.; Arya, J. Balakrishnan, S. Evidence for the involvement of the monoaminergic system, but not the opioid system in the antidepressant-like activity of ellagic acid in mice. Eur. J. Pharmacol. 2012, 682, 118-125. [CrossRef] [PubMed]

44. Porsolt, R.D.; Bertin, A.; Jalfre, M. Behavioral despair in mice: A primary screening test for antidepressants. Arch. Int. Pharmacodyn. Ther. 1977, 229, 327-336. [PubMed]

45. Detke, M.J.; Lucki, I. Detection of serotonergic and noradrenergic antidepressants in the rat forced swimming test: The effects of water depth. Behav. Brain Res. 1996, 73, 43-46. [CrossRef]

46. Aksoz, E.; Aksoz, T.; Bilge, S.S.; Ilkaya, F.; Celik, S.; Diren, H.B. Antidepressant-like effects of echo-planar magnetic resonance imaging in mice determined using the forced swimming test. Brain Res. 2008, 1236, 194-199. [CrossRef] [PubMed]

47. Cryan, J.F.; Markou, A.; Lucki, I. Assessing antidepressant activity in rodents: Recent developments and future needs. Trends Pharmacol. Sci. 2002, 23, 238-245. [CrossRef]

48. Nakatomi, Y.; Yokoyama, C.; Kinoshita, S.; Masaki, D.; Tsuchida, H.; Onoe, H.; Yoshimoto, K.; Fukui, K. Serotonergic mediation of the antidepressant-like effect of the green leaves odor in mice. Neurosci. Lett. 2008, 436, 167-170. [CrossRef] [PubMed]

49. Abreu, T.M.; Monteiro, V.S.; Martins, A.B.S.; Teles, F.B.; da Conceição Rivanor, R.L.; Mota, É.F.; Macedo, D.S.; De Vasconcelos, S.M.M.; Júnior, J.E.R.H.; Benevides, N.M.B. Involvement of the dopaminergic system in the antidepressant-like effect of the lectin isolated from the red marine alga Solieria filiformis in mice. Int. J. Biol. Macromol. 2018, 111, 534-541. [CrossRef] [PubMed]

50. Castagné, V.; Moser, P.; Roux, S.; Porsolt, R.D. Rodent models of depression: Forced swim and tail suspension behavioral despair tests in rats and mice. Curr. Protoc. Neurosci. 2011. [CrossRef]

51. Koe, B.K.; Weissman, A. p-Chlorophenylalanine: A specific depletor of brain serotonin. J. Pharmacol. Exp. Ther. 1966, 154, 499-516. [PubMed]

52. Redrobe, J.P.; Bourin, M.; Colombel, M.C.; Baker, G.B. Dose-dependent noradrenergic and serotonergic properties of venlafaxine in animal models indicative of antidepressant activity. Psychopharmacology 1998, 138, 1-8. [CrossRef] [PubMed]

53. Redrobe, J.P.; Bourin, M.; Colombel, M.C.; Baker, G.B. Psychopharmacological profile of the selective serotonin reuptake inhibitor, paroxetine: Implication of noradrenergic and serotonergic mechanisms. J. Psychopharmacol. 1998, 12, 348-355. [CrossRef] [PubMed]

54. Kwon, S.; Lee, B.; Kim, M.; Lee, H.; Park, H.J.; Hahm, D.H. Antidepressant-like effect of the methanolic extract from Bupleurum falcatum in the tail suspension test. Prog. Neuropsychopharmacol. Biol. Psychiatry. 2010, 34, 265-270. [CrossRef] [PubMed]

55. Can, Ö.D.; Demir Özkay, Ü.; Üçel, U.İ. Anti-depressant-like effect of vitexin in BALB/c mice and evidence for the involvement of monoaminergic mechanisms. Eur J. Pharmacol. 2013, 699, 250-257. [CrossRef] [PubMed]

56. Lian, L.; Xu, Y.; Zhang, J.; Yu, Y.; Zhu, N.; Guan, X.; Huang, H.; Chen, R.; Chen, J.; Shi, G.; et al. Antidepressant-like effects of a novel curcumin derivative J147: Involvement of 5-HT1A receptor. Neuropharmacology 2018, 135, 506-513. [CrossRef] [PubMed]

57. Wang, R.; Xu, Y.; Wu, H.L.; Li, Y.B.; Li, Y.H.; Guo, J.B.; Li, X.J. The antidepressant effects of curcumin in the forced swimming test involve 5-HT1 and 5-HT2 receptors. Eur. J. Pharmacol. 2008, 578, 43-50. [CrossRef] [PubMed] 
58. Karim, N.; Khan, I.; Abdelhalim, A.; Khan, A.; Halim, S.A. Antidepressant potential of novel flavonoids derivatives from sweet violet (Viola odorata $\mathrm{L}$ ): Pharmacological, biochemical and computational evidences for possible involvement of serotonergic mechanism. Fitoterapia 2018, 128, 148-161. [CrossRef] [PubMed]

59. Wang, G.L.; Wang, Y.P.; Zheng, J.Y.; Zhang, L.X. Monoaminergic and aminoacidergic receptors are involved in the antidepressant-like effect of ginsenoside $\mathrm{Rb} 1$ in mouse hippocampus (CA3) and prefrontal cortex. Brain Res. 2018, 1699, 44-53. [CrossRef] [PubMed]

60. Chen, L.; Jin, Y.; Fu, W.; Xiao, S.; Feng, C.; Fang, B.; Gu, Y.; Li, C.; Zhao, Y.; Liu, Z.; et al. Design, Synthesis, and Structure-Activity Relationship Analysis of Thiazolo [3,2-a]pyrimidine Derivatives with Anti-inflammatory Activity in Acute Lung Injury. Chem. Med. Chem. 2017, 12, 1022-1032. [CrossRef] [PubMed]

61. Faraji, L.; Shahkarami, S.; Nadri, H.; Moradi, A.; Saeedi, M.; Foroumadi, A.; Ramazani, A.; Haririan, I.; Ganjali, M.R.; Shafiee, A.; et al. Synthesis of novel benzimidazole and benzothiazole derivatives bearing a 1,2,3-triazole ring system and their acetylcholinesterase inhibitory activity. J. Chem. Res. 2017, 41, 1-63. [CrossRef]

62. Al Omran, F.; Abou El-Khair, A. Synthesis, spectroscopy and X-ray characterization of novel derivatives of substituted 2-(benzothiazol-2'-ylthio)acetohydrazide. IJOC 2016, 6, 31-43. [CrossRef]

63. Bhatt, J.D.; Nimavat, K.S.; Vyas, K.B. Studies on novel thiazolidinone and their biological studies. J. Chem. Pharm. Res. 2013, 5, 327-331.

64. Sanmukhani, J.; Anovadiya, A.; Tripathi, C.B. Evaluation of antidepressant like activity of curcumin and its combination with fluoxetine and imipramine: An acute and chronic study. Acta Pol. Pharm. 2011, 68, 769-775. [PubMed]

65. Tanaka, M.; Telegdy, G. Involvement of adrenergic and serotonergic receptors in antidepressant-like effect of urocortin 3 in a modified forced swimming test in mice. Brain Res. Bull. 2008, 77, 301-305. [CrossRef] [PubMed]

66. Votava, M.; Hess, L.; Slíva, J.; Krsiak, M.; Agová, V. Dexmedetomidine selectively suppresses dominant behaviour in aggressive and sociable mice. Eur. J. Pharmacol. 2005, 523, 79-85. [CrossRef] [PubMed]

Sample Availability: Samples of the compounds are available from the authors.

(C) 2018 by the authors. Licensee MDPI, Basel, Switzerland. This article is an open access article distributed under the terms and conditions of the Creative Commons Attribution (CC BY) license (http://creativecommons.org/licenses/by/4.0/). 